Gutierrez et al., Afr J Tradit Complement Altern Med. (2014) 11(2):231-236

http://dx.doi.org/10.4314/ajtcam.v11i2.1

\title{
EFFECT OF CHRONIC ADMINISTRATION OF HEXANE EXTRACT OF BYRSONIMA CRASSIFOLIA SEED ON B-CELL AND PANCREATIC OXIDATIVE PARAMETERS IN STREPTOZOTOCIN-INDUCED DIABETIC RAT
}

\section{*Rosa Martha Perez Gutierrez and Jose Maria Mota Flores}

\author{
Laboratory for Research on Natural Products, School of Chemical Engineering and Extractive Industries-IPN. Av. Instituto \\ Politécnico Nacional, Unidad Profesional Adolfo Lopez Mateos CP 07758, Mexico D.F. \\ *E-mail: rmpg@prodigy.net.mx
}

\begin{abstract}
Background: In Mexican traditional medicine, the seeds of Byrsonima crassifolia have been used in the treatment of diabetes, rheumatism and for wound healing. The aim was to evaluate the effect of seeds of $B$. crassifolia on insulin release from the pancreatic beta cells in streptozotocininduced diabetic rats.

Materials and Methods: In the present study, we evaluated the beneficial effect of seeds $B$. crassifolia streptozotocin-induced type 1 diabetic rats. Insulin level; insulin sensitivity index, insulin content in pancreas, malonaldehyde, nitric oxide contents, oxidative stress parameters were assayed. Serum glucose levels were determined by the glucose oxidase method. To determine the insulin releasing activity, after extract treatment, the pancreas was excised. Pancreatic sections were processed for examination of insulin-releasing activity using an imunocytochemistry kit.

Results: Administration of the hexane extract $(200$ and $400 \mathrm{mg} / \mathrm{kg})$, exhibited a significant reduction in serum glucose. Administration of streptozotocin decreased the number of beta cells with insulin secretory activity in comparison with intact rats; but treatment with the $B$. crassifolia seed extract increased significantly the activity of the beta cells in comparison with the diabetic control rats. The extract decreased serum glucose in streptozotocin-induced diabetic rats and increased insulin release from the beta cells of the pancreas.

Conclusion: These finding suggest that $B$. crassifolia seed has beneficial effect for diabetes through decreasing blood glucose and lipid levels, increasing insulin sensitivity index and insulin content, up-regulating antioxidant enzyme activity and decreasing lipid peroxidation.
\end{abstract}

Key words: Byrsonima crassifolia, pancreatic $\beta$-cells, antioxidant enzyme, hypoglycaemia rats

\section{Introduction}

Diabetes is a serious metabolic disorder with micro and macro vascular complications resulting in high morbidity and mortality rates. Diabetes is characterized by hyperglicemia, abnormal lipid, and protein metabolism, along with specific long-term complications affecting the retina, the kidney and the nervous system mainly [Setter et al. 2003]. Oxidative stress and advanced glycation endproducts (AGEs), formation induced by hyperglycemia are known to influence diabetic renal changes and nephropathy [Grover et al. 2003]. The number of people with diabetes is increasing globally due to population growth, aging, urbanization, increasing prevalence of obesity, calorie rich diet and physical inactivity. Current treatments, although provide a good glycemic control; do little preventing complications (Modi, 2007). Besides, most of the prescribed hypoglycemic drugs or insulin is associated with unwanted side effects. Because of this there is an increasing demand in research for natural products with anti-diabetic activity [Rang et al., 1991]. Herbal medicines are an option because of their comparably therapeutic effects and nontoxic side effects [Baily et al., 1986].

Byrsonima crassifolia is a tropical tree, commonly known as "nanche", distributed widely in México, Central and South America. Nanche fruit is edible and bright yellow when ripened; it has sweet taste and slightly bitter aftertaste. In México, nanche is consumed as juice, liquor, jelly and candy. Since pre-Hispanic times it has been used as medicine, reports on ethno-botanical uses include: bark, to promote bleeding in females; facilitate childbirth, and snakebite treatment; aerial parts, used as diuretic, febrifuge, to expel placenta and for diarrhea treatment; fruit, used for fever treatment and to induce a pleasant dizziness; bark and branches, assist in tightening loose teeth and fish poison; and finally, seeds for dysentery, wound healing and anti-inflammatory [Bejar et al., 1993]. Phyto-chemical studies indicate that nanche plant contains esters [Alves et al., 2003]; epicatechins [Geiss et al., 1995]; glycolipids [Rastrelli et al., 1997]. A pharmacological study of leaf and bark extracts displayed spasmogenic effects [Bejar et al., 1993]. In another study, a chloroformic extract from bark showed anti-inflammatory activity when evaluated by the Croton oil model [Maldini et al., 2009]. Furthermore, the antioxidant activity of extracts from leaves, fruits and bark has been determinate [Silva et al., 2007]. The ethyl-acetate extract of roots exhibited antibacterial activity Martinez-['Vazquez et al., 1999]. Also, the aqueous extract of leaves inhibited some dermatophytes [Caceres et al., 1993]. The ethanol extract of leaves showed trypanocidal activity against Leishmania mexicana promastigotes [Berger et al., 1998]. Hexane extract was shown to act as hypoglycemic [Perez-Gutierrez et al., 2010].

Therefore, the present study explored the effects of Byrsonima crassifolia fruit and seed extracts obtained with hexane, chloroform and methanol. The extracts obtained with these solvents of increasing polarity were used to evaluate the effect on hypoglycemic, oxidative stress, insulin level in diabetic rodent model and AGEs formation in pancreatic $\beta$-cells in culture.

\section{Materials and Methods \\ Plant material and extract preparation}

Byrsonima crassifolia L. belong to the Malpighiaceae family, fruit were collected in Morelos State, and were taxonomically authenticated in the Herbario of Escuela Nacional de Ciencias Biologicas, Instituto Politécnico Nacional. A voucher specimen of the plant is stored for reference (No. 8976). 300g of the seeds of B. crassifolia were dried, and powdered in a mechanical grinder. The powdered material was extracted by $500 \mathrm{ml}$ of hexane, chloroform, methanol and water consecutively using soxhlet apparatus. These extracts was filtered and concentrated by rotary 
http://dx.doi.org/10.4314/ajtcam.v11i2.1

vacuum evaporator and kept in vacuum desiccators for complete removal of solvent. An aqueous suspension was prepared using $2 \%$ (v/v) Tween80 and then used for oral administration.

Animals

Study was conducted in male Wistar rats, provided by the bioterium of the National School of Biological Sciences. Rats weighted between 180 to $225 \mathrm{~g}$. Animals were housed in microlon boxes in a controlled environment (temperature $25 \pm 2{ }^{\circ} \mathrm{C}$ ), with standard laboratory diet (Mouse Chow 5015, Purina), and water ad libitum. Litter was renewed three times a week to ensure hygiene and maximum comfort for animals. Rats were acclimatized for a period of three days in their new environment before the initiation of the experimental procedures. Ethical clearance for handling animals (NIH publication No. 85-23, revised 1985) was observed at all times.

\section{Induction of experimental diabetes}

Severe diabetes mellitus was induced in overnight fasted male rats by a single intra-peritoneal injection of streptozotocin, at a dose of $50 \mathrm{mg} / \mathrm{kg}$, body weight dissolved in cold citrate buffer ( $\mathrm{pH}$ 4.5) [Maghrani et al., 2004]. Hyperglucemia was confirmed by measuring glucose 72hrs, after the streptozotocin shot and seven days after injection, confirming a high glucose level. Rats with permanent high fasting blood glucose level > $300 \mathrm{mg} / \mathrm{dl}$ were included for the experiments.

\section{Experimental Design}

In the experiment a total 40 , rats for each extract were divided into four groups ( $\mathrm{n}=10$ per group): 1 normal control, 2 diabetes control, groups 3 to 4 correspond to diabetic rats treated with B. crassifolia aqueous reconstituted solution from organic solvent extract at dose of 200 and $400 \mathrm{mg} / \mathrm{kg}$ body weight on a daily basis for 28 , days. All the drugs solutions or vehicle were administered orally by gastric intubations once daily at 9:00am for 28, days. At the end of the experiment rats were fasted overnight and were euthanized by anesthesia. Each pancreas was quickly removed from the sacrificed rat, placed in ice cold saline solution, trimmed of adipose tissue and weighed. Part of each pancreas was finely minced and homogenized in 50mM phosphate buffer, $\mathrm{pH} 7.4$, and centrifuged at $2000 \mathrm{rpm}$ for $10 \mathrm{~min}$ at $4^{\circ} \mathrm{C}$. The supernatant was used for all the assays.

\section{Body weight}

Body weights of rats and the intake of food and water were taken prior to the induction of hyperglycemia, at day 0 of $B$. crassifolia treatment, and on a daily basis thereafter, for 4 weeks.

\section{Serum lipid profile and glucose levels}

The serum determination of total cholesterol (TC); triglycerides (TG); and HDL-cholesterol, using a commercial Diagnostic Kit (Genzyme Diagnostics, MA. USA). Blood glucose levels were measured employing the glucose oxidase-peroxidase (GOD-POD) method Sang-Eun et al. (2007).

\section{Lipid peroxidation and antioxidant enzymes assays}

The tissue homogenate was used for the determination of lipid peroxidation and antioxidant enzyme. Pancreas homogenate was obtained by centrifugation $(3000 \mathrm{Xg})$, in $50 \mathrm{mM}$ phosphate buffer, pH 7.4 at $4^{\circ} \mathrm{C}$, according to the method of [Johnson et al., 1967]. The concentration of TBAreactive substance was determined using malonaldehyde level by Oxis ininternational, CA, USA, and expressed as mol/mg of protein.

Antioxidant enzyme activities in the pancreas were assayed using commercial kits: superoxide dismutase (SOD) assay kit Bioxytech SOD-525, for SOD activity (Oxis International, CA, USA), catalase assay kit for catalase activity (CAT), (Cayman Chemical), and glutathione reductase (GSH), assay kit Bioxytech GR-340, for GR activity, (Oxis International), and glutathione peroxidase (GPx), assay kit GPx-340, for GPx (Oxis International).

\section{Determination of Insulin}

Serum insulin was measured by enzyme linked inmunosorbent assay (ELISA), using the kit (Boehringer Mannheim Diagnostic, Mannheim, Germany). The intra assay variation was $4.9 \%$. As the samples were run at a time; there is no inter-assay variation. The level of insulin in serum was expressed in $\mu \mathrm{IU} / \mathrm{ml}$.

\section{Determination of insulin releasing activity}

To determine the insulin releasing activity of the extract, $3 \mathrm{hrs}$, after extract treatment, the animals were anaesthetized with diethyl ether. Sections of 5:00 $\mu \mathrm{m}$, were processed for insulin-releasing activity using an irnmunocytochemistry kit. Briefly, endo-genous peroxidase activity was blocked with methanol- $\mathrm{H}_{2} \mathrm{O}_{2}\left(30 \% \mathrm{H}_{2} \mathrm{O}_{2}\right.$; diluted 1:30 in methanol), and to reduce non-specific binding to cellular immunoglobulin (Fc)-receptors, the specimens were treated with buffered rat serum (dilution 1:10 in PBS buffer). For insulin detection, a rat polyclonal insulin-antibody (DAKO 
http://dx.doi.org/10.4314/ajtcam.v11i2.1

company) was used as primary antibody (dilution 1:200 in PBS-buffer). Biotinylated anti-rat-F (ab'), 2-fragment (dilution 1:200 in PBS-buffer) served as the secondary antibody. The detection of the specific antibody bonding was accomplished using the avidin-biotin-peroxidase-complex method (DAKO-company) with 3,3'-diaminobenzidine.

\section{Syntheses of advanced glycation end products (AGEs)}

AGEs were generated from co-incubation of BSA with either D-glucose (AGE1) or D-glyceraldhyde (AGE2) according to the method of Chick et al. (1997). AGE1 and AGE2 were incubated at $37^{\circ} \mathrm{C}$ for 8 weeks and 2 weeks, respectively. BSA alone was incubated at $37^{\circ} \mathrm{C}$ for 2 weeks under conditions without any carbohydrates, and employed as the control for AGE1 and AGE2.

\section{Protective effect on pancreatic $\beta$-cells from oxidative stress}

$\beta$-cells are vulnerable to oxidative stress. Thus, in cultured RIN-5F cells, (American Type Culture Collection; number: CRL-2058), we examined whether $B$. crassifolia would protect the pancreas-derived $\beta$-cells from oxidative stress. RIN-5F cells that had been adhered and pre-cultured with medium alone for $72 \mathrm{hrs}$ were treated with HS or medium alone for another $3 \mathrm{hrs}$. At the end of the culture, the intracellular peroxide level was measured with 2',7'-dichloro-dihydrofluorescein diacetate (DCFH-DA) fluorescent probe Marina et al.(2000).

\section{Statistical Analysis}

The effect of $B$. crassifolia aqueous extracts on each parameter was examined using one-way analysis of variance (ANOVA). Individual differences among groups were analyzed by Dunnett's test using SPSS software. P values less than 0.05 were considered as statistically significant. Data are expressed as mean \pm S.E.M. for 6 rats in each group.

\section{Results \\ Effect on blood glucose}

STZ $(50 \mathrm{mg} / \mathrm{kg})$, injection resulted in a significant elevation of blood glucose level. Changes in the plasma glucose concentrations produced by supplementation of the hexane extract of seeds of $B$. crassifolia (NS), to diabetic rats for 14 and 28, days are presented in Table 1 . In contrast with body weight loss, diabetic control rats showed an increase in blood glucose from initial value from 324.7, to final $362.1 \mathrm{mg} / \mathrm{dl}$. One the other hand, $400 \mathrm{mg}$ of $B$. crassifolia-treated diabetic rats showed a significant decrease compared with diabetic control rats (from $349.7 \mathrm{mg} / \mathrm{dl}$ to $99.8 \mathrm{mg} / \mathrm{dl}$ ), resulted a significant recovery of glucose level and resettled to the control level. However, chloroform and methanol extracts to the same doses did not produced hypoglycemic activity. The hypoglycemic study of the hexane extract of the seed was previously published [Perez-Gutierrez et al., 2010].

Table 1: Effect of hexane extract Byrsonima crassifolia (NS) after 28 days treatment on blood glucose level in STZ-induced diabetes

\begin{tabular}{cccc}
$\begin{array}{c}\text { Group } \\
(\mathrm{mg} / \mathrm{kg})\end{array}$ & \multicolumn{2}{c}{ Fasting blood glucose level (mg/d) } \\
& \multicolumn{2}{c}{ Days of NS supplement } & 28 \\
\hline No-diabetic control & 0 & 14 & $90.6 \pm 1.7^{\mathrm{a}}$ \\
Diabetic control & $91.6 \pm 4.6^{\mathrm{a}}$ & $92.4 \pm 2.5^{\mathrm{a}}$ & $362.1^{\mathrm{a}} \pm 5.3^{\mathrm{c}}$ \\
NS 200 & $324.7 \pm 6.5^{\mathrm{c}}$ & $345.2 \pm 6.8^{\mathrm{c}}$ & $115.6^{\mathrm{c}} \pm 4^{\mathrm{b}}$ \\
NS 400 & $358.6 \pm 7.2^{\mathrm{c}}$ & $178.5 \pm 4.6^{\mathrm{b}}$ & $99.8^{\mathrm{b}} \pm 1.1^{\mathrm{a}}$ \\
\hline
\end{tabular}

Each value represents mean \pm S.E.M. $(n=10)$, ANOVA followed by multiple two-tail " $t$ " test. In each vertical column, mean with different superscripts $(a, b, c)$ differ from " $t$ ' each other significantly, $<0.05$.

\section{Body weight and intakes of food, water}

The body weight and food, water intakes in control and experimental animals are shown in Table 2; the induction of STZ-diabetes resulted in elevated intake of both. A significant decrease in body weight during the 28 , days was observed in the diabetic control rats compared with control rats, showing no difference between initial and final values; however, administration of seeds of B. crassifolia at doses of $400 \mathrm{mg}$ to diabetic rats increased body weight gain significantly (from $180.9 \mathrm{~g}$ to $215.6 \mathrm{~g}$ ). Diabetic rats showed increase in food and water intakes as compared to normal control rats but the administration of 200 and $400 \mathrm{mg} / \mathrm{kg}$, of hexane extract led to a decrease in water and food intake in experimental groups.

Table 2: Effect on physico-metabolic symptoms of seeds hexane extract Byrsonima crassifolia (NS)

\begin{tabular}{cccccc}
\hline $\begin{array}{c}\text { Group } \\
(\mathrm{mg} / \mathrm{kg})\end{array}$ & Initial & $\begin{array}{c}\text { Body weight }(\mathrm{g}) \\
\text { Final }\end{array}$ & Gain & Intake $(\mathrm{g} / \mathrm{d})$ \\
Food & water \\
\hline No-diabetic & $218.4 \pm 7.8^{\mathrm{a}}$ & $295.3 \pm 9.8^{\mathrm{a}}$ & $76.9 \pm 2.3^{\mathrm{a}}$ & $21.2 \pm 2.5^{\mathrm{a}}$ & $39.8 \pm 1.8^{\mathrm{a}}$ \\
Diabetic & $176.0 \pm 6.5^{\mathrm{c}}$ & $184.4 \pm 7.8^{\mathrm{c}}$ & $8.4 \pm 1.2^{\mathrm{c}}$ & $34.1 \pm 4.4^{\mathrm{c}}$ & $142.2^{\mathrm{c}} \pm 6.5^{\mathrm{c}}$ \\
NS 200 & $187.5 \pm 5.6^{\mathrm{c}}$ & $208.6 \pm 9.4^{\mathrm{b}}$ & $21.1 \pm 3.6^{\mathrm{b}}$ & $30.3 \pm 4.8^{\mathrm{c}}$ & $121.8 \pm 4.7^{\mathrm{b}}$ \\
NS 400 & $180.9 \pm 5.9^{\mathrm{c}}$ & $215.6 \pm 9.1^{\mathrm{b}}$ & $34.1 \pm 4.9^{\mathrm{a}}$ & $26.0 \pm 1.5^{\mathrm{c}}$ & $112.7^{\mathrm{a}} \pm 4.2^{\mathrm{a}}$ \\
\hline
\end{tabular}

Each value represents mean \pm S.E.M. $(n=10)$, ANOVA followed by multiple two-tail " $t$ " test. In each vertical column, mean with different superscripts $(\mathrm{a}, \mathrm{b}, \mathrm{c})$ differ from $t^{\prime}$ each other significantly, $\mathrm{p}<0.05$. 
http://dx.doi.org/10.4314/ajtcam.v11i2.1

\section{Serum constituents}

Table 3 shows the results of lipids in the serum. Total cholesterol, triglycerides levels of diabetic control rats were significantly increased to the control levels. These parameters were decreased significantly in the hexane extract supplemented groups in respect to the corresponding diabetic groups, and were resettled towards the control level. HDL-cholesterol, a friendly lipoprotein, was decreased in diabetic groups in respect to the control. After 28, days of hexane extract of seeds of B. crassifolia supplementation, there was a significant elevation of this lipoprotein level in serum to and was resettled to the control level.

Table 3: Effect hexane extract seeds of Byrsonima crassifolia (NS) on lipid profile in STZ- induced diabetic rats

\begin{tabular}{|c|c|c|c|}
\hline \multicolumn{4}{|c|}{ Mean Concentration $(\mathrm{mg} / \mathrm{g}) \pm \mathrm{SEM}$} \\
\hline $\begin{array}{l}\text { Group } \\
(\mathrm{mg} / \mathrm{kg})\end{array}$ & $\begin{array}{l}\text { Triglycerides } \\
(\mathrm{mg} / \mathrm{dl})\end{array}$ & $\begin{array}{l}\text { Total cholesterol } \\
(\mathrm{mg} / \mathrm{dl})\end{array}$ & $\begin{array}{l}\text { HDL-cholesterol } \\
(\mathrm{mg} / \mathrm{dl})\end{array}$ \\
\hline Normal control & $90.79 \pm 3.48$ & $130.12 \pm 5.76$ & $68.87 \pm 3.48$ \\
\hline Diabetic control & $185.56 \pm 6.13^{a}$ & $249.38 \pm 3.26^{a}$ & $34.25 \pm 4.19 \mathrm{a}$ \\
\hline NS 200 & $130.16 \pm 3.76^{\mathrm{ab}}$ & $154.67 \pm 4.12^{\mathrm{ab}}$ & $50.39 \pm 3.49^{a b}$ \\
\hline NS 400 & $92.05 \pm 3.60^{\mathrm{ab}}$ & $131.26 \pm 4.74 \mathrm{ab}$ & $60.45 \pm 3.41 \mathrm{ab}$ \\
\hline
\end{tabular}

All values are expressed as Mean \pm SEM, $n=6$ Values. a $\mathrm{P}<0.05$ when compared to normal control group, bP<0.01 when compared to diabetic control group, where the significance was performed by Oneway ANOVA followed by post hoc Dunnett's test.

\section{Insulin concentration}

Serum insulin level was significantly decreased in diabetic rats in respect to control. After 28, days of hexane extract of seeds of $B$. crassifolia supplementation to the diabetic rats, there was a significant elevation in serum insulin level in respect to diabetic-control group though the level of this hormone was significantly low than the control (Table 5). In pancreas insulin level with extract supplementation (200 and $400 \mathrm{mg} / \mathrm{kg}$ ) resulted also in significant variation in insulin level in respect to only diabetic-control. Treatment group increased active $\beta$ cells.

Table 4: Effect hexane extract seeds of Byrsonima crassifolia (NS) on antioxidant enzyme, TBARS in pancreas

\begin{tabular}{ccccc}
\hline Parameters & Normal Control & Diabetic control & $\begin{array}{c}\text { Diabetic+NS } \\
(200 \mathrm{mg} / \mathrm{kg})\end{array}$ & $\begin{array}{c}\text { Diabetic+NS } \\
(400 \mathrm{mg} / \mathrm{kg})\end{array}$ \\
\hline SOD & $55.05 \pm 1.78$ & $36.38 \pm 2.72^{\mathrm{a}}$ & $46.34 \pm 2.65^{\mathrm{b}}$ & $50.19 \pm 3.19^{\mathrm{b}}$ \\
CAT & $60.12 \pm 2.61$ & $24.58 \pm 3.28^{\mathrm{a}}$ & $48.36 \pm 2.87^{\mathrm{a}}$ & $53.61 \pm 4.17 \mathrm{c}$ \\
GSH & $13.28 \pm 1.92$ & $5.52 \pm 1.57^{\mathrm{a}}$ & $9.40 \pm 1.14^{\mathrm{b}}$ & $11.78 \pm 2.54^{\mathrm{b}}$ \\
GPx & $4.51 \pm 2.36$ & $2.62 \pm 1.21^{\mathrm{a}}$ & $3.43 \pm 1.33^{\mathrm{b}}$ & $3.98 \pm=0.98^{\mathrm{b}}$ \\
TBARS (mM/mg & $1.91 \pm 0.34$ & $2.78 \pm 1.01^{\mathrm{a}}$ & $2.01 \pm 0.15^{\mathrm{ab}}$ & $1.94 \pm 0.13^{\mathrm{ab}}$ \\
protein) & & &
\end{tabular}

All values are expressed as Mean $\pm \mathrm{SEM}, \mathrm{n}=6$ Values. $\mathrm{a}<<0.01$ when compared to normal control group; $\mathrm{bP}<0.01 \mathrm{cP}<0.05$ compared to diabetic control group; where the significance was performed by Oneway ANOVA followed by post hoc Dunnett's test. The activities of antioxidant enzyme are given in $\mathrm{U} / \mathrm{mg}$ of protein.

\section{Insulin releasing activity}

Administration of streptozotozin decreased the number of beta cells with insulin releasing activity in comparison with intact rats. However, treatment of seed extract ( 200 and $400 \mathrm{mg} / \mathrm{kg}$ ) increased active beta cells in comparison with diabetic control (Table 5).

\section{Effect on pancreatic AGEs}

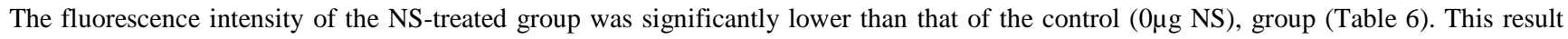
suggested that NS might reduce oxidative stress in RIN-5F cells. To verify this hypothesis, RIN-5F cells were given oxidative stress by adding AGE1 and AGE2, BSA conjugated with glucose and glyceraldehyde, respectively, to experimental media. Control cells were incubated with BSA alone. After 3hrs, treatment with AGEs, fluorescence intensity of AGE1 and AGE2-treated cells was significantly higher than that of the BSA-treated cells. In the same experiments with AGEs, treatment of RIN-5F cells with NS for $3 \mathrm{hrs}$ resulted in dramatic reductions in oxidative stress with significant differences. These results clearly defined that of seeds of $B$. crassifolia was capable to protect pancreatic $\beta$-cells from AGEs-induced oxidative stress.

Table 5: Effect of NS on pancreatic insulin levels in serum and pancreas

\begin{tabular}{ccc}
\hline Groups $(\mathrm{mg} / \mathrm{kg})$ & Serum insulin $(\mathrm{mlU} / \mathrm{ml})$ & $\begin{array}{c}\text { Pancreatic insulin } \\
(\mathrm{mU} / \mathrm{g} \text { protein) }\end{array}$ \\
\hline Normal control & $13.94 \pm 3.7^{\mathrm{a}}$ & $26.92 \pm 3.7^{\mathrm{a}}$ \\
Diabetic control & $10.98 \pm 3.1^{\mathrm{b}}$ & $17.67 \pm 2.6^{\mathrm{b}}$ \\
NS 200 & $12.38 \pm 4.5^{\mathrm{b}}$ & $20.23 \pm 1.4^{\mathrm{c}}$ \\
NS 400 & $13.56 \pm 4.1^{\mathrm{c}}$ & $25.16 \pm 1.2^{\mathrm{d}}$ \\
\hline
\end{tabular}

Data are expressed as mean: \pm S.E.M.: $n=10$. ANOVA followed by multiple two tail " $t$ "test. Different superscripts $(a, b, c, d)$ differ from each other significantly $(p<0.05)$. 


\section{Discussion}

When rats are injected with streptozotocin, they provide an animal model of non-insulin-dependent diabetes mellitus. In this model, the destruction of $\beta$-cells and disorder of insulin secretion in the diabetic state causes physic-metabolic abnormalities such as higher levels of fasting and fed glucose levels, lower body weight, increase in food and water intakes as compared to normal control rats.

Treatment with seeds of $B$. crassifolia significantly reduced body weight loss, food and water intakes. Those observations could be due to an improvement of elevated blood glucose and the effect of the plant extract on lipolysis. Administration of NS at doses of 200 and $400 \mathrm{mg} / \mathrm{kg}$ significantly decreased serum glucose in streptozotocin-induced diabetic fasted animals and also increased the activity of beta cells in comparison with the diabetic control rats.

Table 6: Effect of NS on AGEs-induced oxidative stress in pancreatic culture RIN-5F cells

\begin{tabular}{cc}
\hline Groups & Fluorescence \\
BSA & Intracellular ROS level \\
\hline BSA+ NS + RIN-5F & $13.4 \pm 2.45^{\mathrm{a}}$ \\
AGE1 + RIN-5F & $6.2 \pm 1.23^{\mathrm{c}}$ \\
AGE1+ RIN-5F + NS & $20.32 \pm 3.41^{\mathrm{a}}$ \\
AGE2 + RIN-5F & $8.76 \pm 1.19^{\mathrm{b}}$ \\
AGE2 + RIN-5F + NS & $31.23 \pm 4.21^{\mathrm{a}}$ \\
\hline
\end{tabular}

Data are expressed as mean: \pm S.E.M. Different superscripts $(a, b, c, d)$ differ from each other significantly $(p<0.05)$.

Hyperglycemia-induced oxidative stress plays a key role in the development of diabetes or its complications. On the other hand, reactive oxygen species are well known as important risk factors for pancreas diseases. These facts indicate that hyperglycemia-induced oxidative stress may also cause pancreas cell damage. It is possible that the antioxidant defense system against oxidative stress induced by chronic hyperglycemia plays an important role in the pathogenesis of pancreas disease.

Our results showed that the chronic administration of NS seeds improves impairments of SOD activity and glutathione homeostasis in STZinduced diabetic rat pancreas with lowering the blood glucose level. In particular, the diabetes-associated free radical injury, accumulation of lipid peroxidation products, depletion of GSH, decrease in GSH/GPx ratio and down-regulation of key antioxidant enzymes, have been detected not only in the liver but also in pancreas. Accordingly, there was a decrease in GSH in the pancreas of diabetic rats, probably due to increased utilization following the diabetes-induced oxidative stress. Previous studies have reported that there was an increased lipid peroxidation in the pancreas of diabetic rats [Yilmaz et al., 2004]. That that could be due to increased oxidative stress in the cell as a result of depletion of antioxidant scavenger systems.

A significant increase in TBA-reactive substance, an index of endogenous lipid peroxidation, has been shown under diabetic conditions. Therefore, the measurement of TBA-reactive substance is frequently used to determine the level of oxidative stress in diabetic patients. In addition, the increased lipid per-oxidation in the pancreas implies the level of susceptibility of diabetic oxidative stress. Lipid peroxide-mediated tissue damage has been observed in the development of type 1 and type II diabetes (Feillet-coudray et al., 1999).

The repeated administration of NS increased the GSH content in the pancreas leading to a restoration of the defense mechanism and significantly decreased the pancreas lipid peroxidation. NS may help to control free radicals and offered protection to cells against oxidative stress by scavenging free radicals. These results suggest that $B$. crassifolia may act as a suppressor against pancreas cell damage and inhibit the progression of pancreas dysfunction induced by chronic hyperglycemia. It is well known that chronic hyperglycemia leads to the auto-oxidation of glucose and causes the nonenzymatic glycation of proteins through Maillard's reaction which produces Schiff base, Amadori product, and finally AGEs [Schmidt et al., 2001]. In these processes, reactive oxygen species are produced. To avoid oxidative stress, antioxidant enzymes play an important role against oxidative stress. However, hyperglycemia also causes nonenzymatic glycation of these antioxidant enzymes [Eizirik et al., 1992]. In the diabetic state, glycation reaction is observed in various tissues and organs, and various kinds of glycated proteins such as glycosylated hemoglobin, albumin, and lens crystalline are produced in a non enzymatical manner through the glycation reaction. In the present study, B. crassifolia lowered the level of blood glucose significantly as compared with that of the diabetic control group. Therefore, our data demonstrated that NS protected RIN-5F cells from AGEs-induced oxidative stress which is followed by decreasing insulin gene expression and secretion [Lim et al., 2008]. Although, the serum insulin level of the NS group tended to increase as compared with that of the diabetic control suggesting that NS might partially rescue exhausted pancreatic $\beta$-cells of rats from further AGEs-induced oxidative stress. AGEs might deteriorate function of pancreatic beta cells in patients with long-term hyperglycemia.

In conclusion, B. crassifolia seeds prevents hyperglycemia-induced oxidative stress in the pancreas using STZ-induced type-I diabetic rat models. As a result, we found that the chronic administration of NS mitigates the pancreas dysfunction in STZ-diabetic rat via the improvement of the antioxidant defense system. However, we did not try to determine which ingredient(s) of this seeds exerts this beneficial effect. Further study will be needed.

\section{References}

1. Alves, G.L., and Franco, M.R.B. (2003). Headspace Gas Chromatography-Mass Spectrometry of Volatile Compounds in Murici (Byrsonima crassifolia). J. Chromatogr. A., 985: 297-301.

2. Baily, C., and Flatt, P.R. (1986). Anti diabetic Drug, New Development. Indian Biotech.,6: 139-142.

3. Bejar, E., and Malone, M.H. (1993). Pharmacological and Chemical Screening of Byrsonima crassifolia a Medicinal Tree from México. Part I. J Ethnopharm., 39: 141-158. 
http://dx.doi.org/10.4314/ajtcam.v11i2.1

4. Berger, I., Barrientos, A.C., Cáceres, A., Hernández, M., Rastrelli, L., Passreiter, C.M., and Kubelka, W. (1998). Plants used in Guatemala for the Treatment of Protozoal Infections: Activity of Extracts and Fractions of Five Guatemalan Plants Against Trypanosoma cruzi. J. Ethopharmacol., 62:107-115.

5. Caceres, A., Brenda, B., Lopez, R., Giron, M.A., and Logemann, H. (1993). Plants Used in Guatemala for the Treatment of Dermatophytic Infections. I. Screning for Antimycotic Activity of 44 Plant Extracts. J. Ethnopharmacol., 40: 207-213.

6. Chick, W.L., Warren, S., Chute, R.N., Like, A.A., Lauris, V., and Kitchen, K.C.A. (1997). Transplantable Insulinoma in the Rat. Proc Natl Acad Sci. USA. 74:628-632.

7. Eizirik, D.L., Korbutt, G.S., and Hellerström, C. (1992). Prolonged Exposure of Human Pancreatic Islets to High Glucose Concentrations In vitro Impairs the Beta-Cell Function. J. Clin. Invest., 90:1263-1268.

8. Feillet-coudray, E., Rock, E., and Coudrav, A. (1999). Lipid Peroxidation and Antioxidant Status in Experimental Diabetes. Glin. Ghim. Acta. 284: $31-43$.

9. Geiss, F., Heinrich, M., Hunkler, D., and Rimplerl, H. (1995). Proanthocyanidins with (+)- Epicatechin Units From Byrsonima crassifolia bark. Phytochemistry., 39: 635-643.

10. Grover, J.K., Yadav, S.P., and Vats V. (2003). Effect of Feeding Murraya koeingii and Brassica juncea Diet on [correction] Kidney Functions and Glucose Levels in Streptozotocin Diabetic Mice. J. Ethnopharmacol., 85:1-5.

11. Johnson, D., and Lardy, H. (1967). Isolation of Liver or Kidney Mitochondria. In Methods in Enzymology, Eds. R. W. Estabrook and M. E. Pullman. Academic Press, New York. 10 : 94-96.

12. Lim, M., Park, L., Shin, G., Hong, H., Kang, I., and Park, Y. (2008). Induction of Apoptosis of Beta Cells of the Pancreas by Advanced Glycation End-Products, Important Mediators of Chronic Complications of Diabetes Mellitus. Ann NY Acad Sci., 1150:311-315.

13. Maghrani, M., Zeggwagh, N.A., and Lemhadri, A. (2004). Study of the Hyperglycemic Activity of Fraxinus excelsior and Silybum marianum in an Animal Model of Type 2 Diabetes Mellitus. J Ethnopharmacol., 91: 309- 316.

14. Maldini, M., Sosa, S., Montoro, P., Giangaspero, A., Balick, M.J., Pizza, C.D., and Loggia, R. (2009). Screening of the Topical AntiInflammatory Activity of the Bark of Acacia cornigera Willdenow, Byrsonima crassifolia Kunth, Sweetia panamensis Yakovlev and the leaves of Sphagneticola trilobata Hitchcock. J Ethnopharmacol., 122: 430-433.

15. Marina, C., Aldini, G., Piccone, M., and Facino, M.N. (2000). Fluorescent Probes as Markers of Oxidative Stress in Keratinocyte Cell lines Following UVB Exposure. Farmaco., 55: 526-534.

16. Martinez-Vazquez, M., Gonzalez-Esquinca, A.R., Cazares, L.L., Moreno, G.M.N., and Garcia-Argaer, A.N. (1999). Antimicrobial Activity of Byrsonima crassifolia (L.). H.B.K. J. Ethnopharmacol., 66: 79-82.

17. Modi, P. (2007). Diabetes Beyond Insulin: Review of New Drugs for Treatment of Diabetes Mellitus. Curr Drug Discov Technol., 4: 39-47.

18. Perez-Gutierrez, R.M., Muñiz-Ramirez, A., Gomez Gomez, Y., and Bautista-Ramirez, E. (2010). Antihyperglycemic, Antihyperlipidemic and Antiglycation of Byrsonima crassifolia Fruits. Plant Foods Hum Nutr. Aug 18; 20717728.

19. Rang, H.P., and Dale, M.M. (1991). The Endocrine System Pharmacology. 2nd ed. UK: Longman, Harlow: 514-516.

20. Rastrelli, L., De Tommasi, N., Berger, I., Caceres, A., Saravia, A., and De Simona, F. (1997). Glycolipids from Byrsonima crassifolia. Phytochemistry., 45: 647-650.

21. Sang-Eun, P., Mee-Hyun, C., Jin-Kyu, L., Jong-Sang, K., Jeong-Hwan, K., Dae, Y.K., and Cheon-Seok, P. (2007). A New Colorimetric Method for Determining the Isomerization Activity of Sucrose Isomerase. Bioscience Biotech Bioch., 71: 583-586.

22. Schmidt, A.M., Yan, S.D., Yan, S.F., and Stern, D.M. (2001). The Multiligand Receptor RAGE as a Progression Factor Amplifying Immune and Inflammatory Responses. J. Clin. Invest., 108: 949-955.

23. Setter, S.M., Campbell, R.K., and Cahoon, C.J. (2003). Biochemical Pathways for Microvascular Complications of Diabetes Mellitus. Annals Pharmacother., 37: 1858- 1866.

24. Silva, E.M., Souza, J.N.S., Rogez, H., Rees, J.F., and Larondelle, Y. (2007). Antioxidant Activities and Polyphenolic Contents of Fifteen Selected Plant Species from the Amazonian Region. Food Chem., 101:1012-1018.

25. Yilmaz, H.R., Uz, E., Yucel, N., Altuntas, L., and Ozcelik, N. (2004). Protective Effect of Caffeic Acid Phenethyl Ester (CAPE) on Lipid Peroxidation and Antioxidant Enzymes in Diabetic Rat Liver. J Biochem. Mol. Toxicol., 18: 234-238. 